\title{
ГЕОМЕТРИЈСКА НЕПРЕКИДНОСТ
}

Сажетак: Циљ рада је савремено заснивање геометријске теорије непрекидности, која се темељи на двема аксиомама четврте групе - Архимедовом и Канторовом аксиомом. Доказане су разне последиче Архимедове и Канторове аксиоме, попут Канторове и Дедекиндове теореме. Дат је посебан осврт на Хилбертово аксиоматско заснивање геометрије, које уместо Канторове аксиоме користи аксиому линеарне потпуности. На крају, рад илуструје употребу аксиома непрекидности и њихових последица у доказивању неких теорема.

Кључне речи: Аксиоме непрекидности, Архимедова аксиома, Канторова аксиома, Дедекиндова теорема, Аксиома линеарне потпуности.

\section{1. Историјски развој}

Геометрија као научна дисциплина има своју дугу и богату традицију. Када су негде у VI веку пре нове ере водећу улогу у култури и науци преузели Грци, геометрија почиње да се развија једним сасвим новим путем. Индуктиван метод налажења тврђења био је замењен дедуктивним методом, којим се, најпре, установљују општа тврђења, да би се затим из њих добила појединачна сазнања. Старогрчки филозоф и математичар Талес први је дошао до начела да је потребно доказивати геометријска тврђења. Ово начело у много већој мери почео је да спроводи чувени филозоф и математичар Питагора (око 580-око 500. пре н. е.).

Мноштво доказаних геометријских тврђења је било довољно да се постави питање редоследа њиховог излагања. Тај редослед у доказивању геометријских тврђења је представљао једно ново начело, тзв. начело систематизације. Најсистематичнија књига из геометрије античких времена која је доспела до нас су Елементи, дело старогрчког математичара Еуклида (око 365-270. пре н. е.). Међутим, Еуклид је подразумевао геометријску непрекидност, па већ у првом ставу прве књиге својих Елемената, доказујући да постоји правилан троугао коме су задата темена $A$ и $B$, конструише кругове $k(A, A B)$ и $k(B, B A)$ и без доказа за-

\footnotetext{
* Рад је додатак мастер тези Еквивалентни облици аксиоме непрекидности скупа реалних бројева која је одбрањена 16. октобра 2012. године на Математичком факултету у Београду под менторством проф. др Зорана Каделбурга.
} 
кључује да они имају заједничких тачака. Слично, у дванаестом ставу прве књиге, конструишући управну из задате тачке $A$ на правој $p$, Еуклид претпоставља да сваки круг са средиштем $A$, који има тачака са оне стране праве $p$, са које није $A$, сече праву $p$ у двема тачкама. Потреба да се оваква тврђења докажу није исказивана све до друге половине прошлог века када је Паш 1882. године, у својој Новијој геомеmpuju, истакао неопходност заснивања геометријске непрекидности полазећи од засебних аксиома.

\section{2. Аксиоме непрекидности}

Аксиоме геометрије сврставамо у пет група:

1) девет аксиома припадања или аксиома инциденције изражава скуповне односе између тачака, правих и међу равнима;

2) шест аксиома распореда изражава основне особине релације $\mathcal{B}$ (између);

3) седам аксиома подударности изражава особине релације $\mathcal{C}$ (подударно);

4) две аксиоме непрекидности;

5) аксиома паралелности.

Геометријска теорија непрекидности се темељи на двема аксиомама четврте групе, од којих се прва назива Архимедовом или Архимед-Еудоксовом, а друга Канторовом.

A 1. Ако су $A B$ и $C D$ две произвољне дужи, тада на полуправој $A B$ постоји коначан низ тачака $A_{1}, A_{2}, \ldots, A_{n}$ таквих да је $B \in\left(A_{n-1}, A_{n}\right) \quad$ и $\mathcal{B}\left(A_{1}, A_{2} \ldots A_{n}\right)$, при чему је свака од дужи $A A_{1}, A_{1} A_{2}, \ldots, A_{n-1} A_{n}$, подударна дужи $C D$.

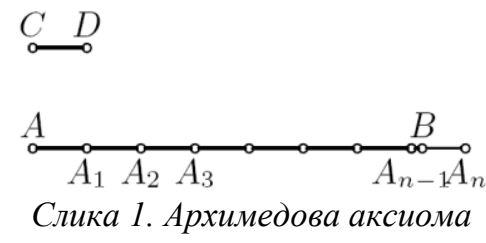

A 2. Ако је $A_{1} B_{1}, A_{2} B_{2}, \ldots, A_{n} B_{n}, \ldots$ бесконачан низ затворених дужи неке праве, таквих да свака од тих дужи садржи следећу, тада постоји тачка $X$ која припада свакој дужи тога низа.

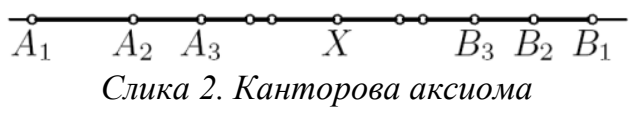


Аналогно се дефинишу одговарајуће аксиоме непрекидности за углове.

A.1'. Ако су $\angle A O B$ и $\angle C O D$ два произвољна позитивно оријентисана угла, тада у равни $A O B$ постоји коначан низ полуправа $O A_{1}, O A_{2} \ldots O A_{n}$, таквих да полуправа $O B$ припада углу $A_{n-1} O A_{n}$ и углови $A O A_{1}, A_{1} O A_{2} \ldots A_{n-1} O A_{n}$ су суседни при чему је сваки од углова $A O A_{1}, A_{1} O A_{2} \ldots A_{n-1} O A_{n}$ подударан углу $C O D$.

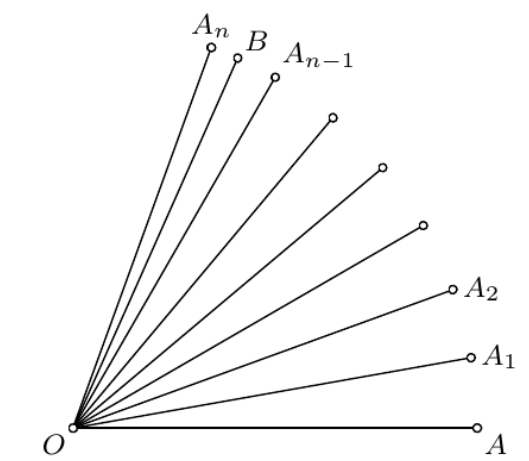

Слика 3. Архимедова аксиома за углове

A.2'. Ако је $\left[\angle A_{1} O B_{1}\right],\left[\angle A_{2} O B_{2}\right], \ldots,\left[\angle A_{n} O B_{n}\right], \ldots$ бесконачан низ затворених углова неке равни, таквих да сваки од тих углова садржи следећи, тада постоји полуправа $O X$ која припада сваком углу тога низа.

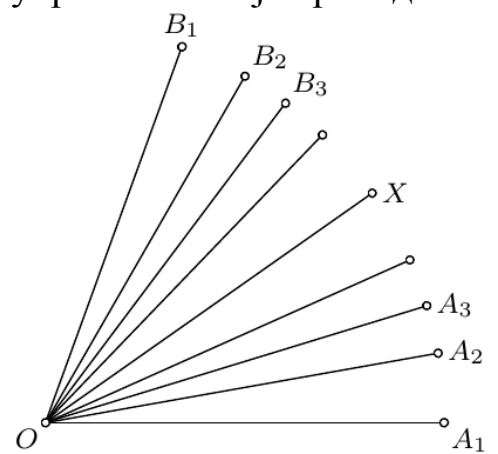

Слика 4. Канторова аксиома за углове

Хилберт у својој књизи Основе геометрије уместо Канторове аксиоме користи аксиому линеарне потпуности, а затим доказује и одговарајући став:

А 3. Систем тачака неке праве са својим релацијама распореда и конгруенције $^{1}$ не може се тако проширити, да остану очуване релације које постоје између претходних елемената, као и основне особине линеарног распореда и конгруенције које проистичу из прве три групе аксиома и Архимедове аксиоме.

\footnotetext{
${ }^{1}$ Хилберт овај термин користи као синоним за ,,једнакост“, „подударност“.
} 
Под основним особинама линеарног распореда Хилберт подразумева:

- прве три аксиоме распореда;

- ма које четири тачке једне праве могу се увек означити са $A, B, C, D$ тако да за тачку $B$ важи распоред $\mathcal{B}(A, B, C)$ и $\mathcal{B} A, B, C$, а за тачку $C$ важи $\mathcal{B}(A, C, D)$ и $\mathcal{B}(B, C, D)$ (тј. $\mathcal{B}$ $(A, B, C, D))$;

- прве три аксиоме подударности;

- једнозначност преношења дужи.

Став. (став потпуности): Елементи геометрије (тј. тачке, праве и равни) образују систем који, уз прве три групе аксиома и Архимедову аксиому, не допушта више никакво проширење помоћу тачака правих и равни.

Доказ. Претпоставимо супротно - да се систем може проширити неким новим елементом. Претпоставка неког новог елемента непосредно доводи до претпоставке неке нове тачке $N$. Елементе који постоје пре проширења назваћемо старим елементима.

Према осмој аксиоми инциденције постоје четири тачке $A, B, C, D$ које нису у једној равни. Ознаке се могу тако изабрати да тачке $A, B, N$ не леже на једној правој. Обе равни $A B N$ и $A C D$, различите једна од друге, имају, према седмој аксиоми инциденције, осим заједничке тачке $A$, још и заједничку тачку $E$. Тачка $E$ не лежи на правој $A B$, јер би иначе тачка $B$ лежала у равни $A C D$. У случају да је $E$ нова тачка, онда у старој равни $A C D$ лежи нова тачка $E$; у случају пак да је $E$ стара, нова тачка $N$ лежи у старој равни, наиме, у равни $A B E$. У сваком случају, дакле, нова тачка лежи у старој равни.

У старој равни постоји стари троугао $F G H$, а на дужи $F G$ стара тачка $I$. Ако спојимо нову тачку $L$ са тачком $I$, тада ће се, према четвртој аксиоми распореда, праве $I L$ и $F H$ или праве $I L$ и $G H$ сећи у тачки $K$, ако нова тачка $L$ не лежи на правој $I H$.

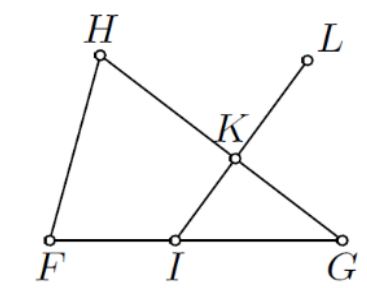

Слика 5. Став потпуности

У случај да је $K$ нова тачка, то нова тачка $K$ лежи на старој правој $F G$ или $G H$; у случају пак да је $K$ стара тачка, онда нова тачка $L$ лежи на старој правој $I K$. Дакле, све три претпоставке противурече 
аксиоми линеарне потпуности. Према томе, треба одбацити претпоставку нове тачке у старој равни и тиме, уопште, претпоставку нових елемената.

\section{3. Последице Архимедове и Канторове аксиоме}

Tеорема 1. Ако је дуж $a$ мања од дужи $b$, тада постоји природан број $n$ такав да је $(n-1) a \leq b<n a$.

Доказ. Теорема је тривијална последица Архимедове аксиоме.

Tеорема 2. Ако је дуж $a$ мања од дужи $b$, онда за сваку дуж $c$ постоје природни бројеви $m$ и $n$ такви да је $a<\frac{m}{2^{n}} c<b$.

Доказ. Како је $b-a>0$ на основу Архимедове аксиоме постоји природан број $n$ такав да је $c<2^{n}(b-a)$ па је $\frac{1}{2^{n}} c<b-a$.

Ako je $\frac{1}{2^{n}} c>a$, онда је $a<\frac{1}{2^{n}} c<b-a<b$, па је теорема доказана за случај $m=1$.

Ако је $\frac{1}{2^{n}} c<a$, онда, на основу претходне теореме, постоји број $m$ такав да је $(m-1) \frac{1}{2^{n}} c \leq a<m \frac{1}{2^{n}} c$.

Тада је $a<\frac{m}{2^{n}} c=\frac{1}{2^{n}} c+\frac{m-1}{2^{n}} c<(b-a)+a=b$.

Дефиниција 1. Канторов низ је низ дужи $\left(A_{k} B_{k}\right)_{k=1,2 \ldots .}$ који задовољава аксиому (2), такав да не постоји дуж која је садржана у свим дужима тога низа.

Теорема 3. (Канторова теорема). Постоји јединствена тачка која припада Канторовом низу.

Доказ. Нека је $X$ тачка чије је постојање претпостављено Канторовом аксиомом. Претпоставимо да постоји, поред тачке $X$, и нека друга тачка $Y$, која припада свакој од дужи датог низа, онда би тачка $Z$ дужи $X Y$ припадала свакој дужи Канторовог низа, што није у складу са његовом дефиницијом. Тиме је доказана јединственост тачке $X$.

Теорема 4. Не постоји дуж која би била мања од сваке дужи Канторовог низа.

Доказ. На основу претходне теореме, постоји јединствена тачка $X$, садржана у свим дужима Канторовог низа дужи $\left[A_{k} B_{k}\right]_{k=1,2 . .}$ на правој 
$p$. Како су за свако $k, A_{k}$ и $B_{k}$ са разних страна тачке $X$, можемо претпоставити да су све тачке $A_{k}$ са једне, а све тачке $B_{k}$ са друге стране тачке $X$. Пошто је дуж $A_{k} B_{k}$ унија дужи $A_{k} X$ и $X B_{k}$, а садржи дуж $A_{k+1} B_{k+1}$, тачка $A_{k+1}$ припада дужи $A_{k} X$, а тачка $B_{k+1}$ припада дужи $X B_{k}$.

Ако је $x$ произвољна дуж, на правој $p$ постоји тачка $A$ са оне стране $X$ са које су и све тачке $A_{k}$, и тачка $B$ са оне стране $X$ са које су и све тачке $B_{k}$ таква да је $X$ средиште $A B$ која је подударна датој дужи $x$. Када на дужи $A X$ не би било ниједне од тачака $A_{k}$, било би за свако $k, \mathcal{B}\left(A_{k}, A, X\right)$, па би дуж $A X$ припадала свакој од дужи Канторовог низа. Дакле, за довољно велико $n$ све тачке $A_{k}, k>n$ су између $X$ и $B$ па, за довољно велико $n$, дуж $A B$ садржи сваку од дужи $A_{n} B_{n}$. Стога је $A_{n} B_{n}<A B=x$.

Дакле, за довољно велико $n$, дужи $X A_{n}$ и $X B_{n}$ су мање од било које унапред задате дужи.

Теореме аналогне последицама Архимедове аксиоме и Канторове аксиоме могу се показати и за углове.

Још једна значајна последица аксиома непрекидности је Дедекиндова теорема.

Tеорема 5. (Дедекиндева теорема за праву). Ако су све тачке неке праве $p$ подељене у два скупа $\mathcal{M}$ и $\mathcal{N}$, таква да:

(1) Свака тачка праве $p$ припада само једном од скупова $\mathcal{M}$ и $\mathcal{N}$,

(2) скупови $\mathcal{M}$ и $\mathcal{N}$ су непразни,

(3) између било којих двеју тачака једног од тих скупова нема тачака које припадају другом, тада постоји јединствена тачка $X$ на правој $p$ таква да су све остале тачке скупа $\mathcal{M}$ са једне стране те тачке, а остале тачке скупа $\mathcal{N}$ са друге.

У исказу Дедекиндове теореме може изоставити јединственост тачке $X$. Наиме, једноставно се може доказати да је тачка $X$ са траженим својствима јединствена.

Доказ. Како су скупови $\mathcal{M}$ и $\mathcal{N}$ непразни, постоје тачке $M_{1}$ и $N_{1}$ које припадају скуповима $\mathcal{M}$ и $\mathcal{N}$ респективно. Означимо са $S_{1}$ средиште дужи $M_{1} N_{1}$. Тачка $S_{1}$ припада правој $p$ на основу услова (1), припада тачно једном од скупова $\mathcal{M}$ и $\mathcal{N}$. Ако тачка $S_{1}$ припада скупу $\mathcal{M}$, обележићемо је са $M_{2}$, а тачку $N_{1}$ са $N_{2}$, а ако $S_{1}$ припада скупу $\mathcal{N}$, обележићемо је са $N_{2}$, а $M_{1}$ са $M_{2}$. Нека је $S_{2}$ средиште дужи $M_{2} N_{2}$. Понављајући започети поступак одредићемо тачке $M_{3}$ и $N_{3}$ 
итд. На тај начин конструисаћемо низ $\left[M_{k} N_{k}\right]_{k=1,2 \ldots}$ затворених дужи, од којих свака дуж садржи следећу у том низу. Такав низ зовемо низом полинома дужи.

Докажимо да не постоји дуж која је садржана у свим дужима конструисаног низа половина. Ако би, напротив, постојала таква дуж $r$, онда би за свако $k$ било $x<\left(1 / 2^{k-1}\right) M_{1} N_{1}$, тј. $2^{k-1} x<M_{1} N_{1}$ за свако $k$, што противречи Архимедовој аксиоми. Дакле, низ $\left[M_{k} N_{k}\right]_{k=1,2 \ldots}$ је Канторов, па постоји јединствена тачка $X$ која припада свакој дужи низа половина дужи.

Из конструкције низа дужи следи да су све тачке низа $\left(M_{k}\right)_{k=1,2 \ldots}$ са једне стране тачке $X$, а све тачке низа $\left(N_{k}\right)_{k=1,2 \ldots}$ са друге. Докажимо да су и све остале тачке скупа $\mathcal{M}$ са једне стране тачке $X$, а све остале тачке скупа $\mathcal{N}$, са друге. Тачка $X$ припада само једном од скупова $\mathcal{M}$ и $\mathcal{N}$, рецимо скупу $\mathcal{N}$. Ако је $X$ произвољна тачка скупа $\mathcal{N}$ различита од $X$, тада је она са оне стране $X$, са које су и тачке низа $\left(N_{k}\right)_{k=1,2 . .}$. Заиста, ако би било $\mathcal{B}\left(N, X, N_{k}\right)$ тачка $N$ би била са стране $X$ са које су и тачке низа $\left(M_{k}\right)_{k=1,2 . .}$ па би, за довољно велико $k$, тачка $M_{k}$ била између $N$ и $X$. Дакле, постојала би тачка скупа $\mathcal{M}$ између двеју тачака скупа $\mathcal{N}$.

Ако је пак $M$ произвољна тачка скупа $\mathcal{M}$, тада не може бити $\mathcal{B}$ $\left(M_{k}, X, N\right)$ јер би постојала тачка скупа $\mathcal{N}$ између двеју тачака скупа $\mathcal{M}$. Дакле, постоји јединствена тачка $X$, таква да су све остале тачке скупа $\mathcal{M}$ са једне стране тачке $X$, а све остале тачке скупа $\mathcal{N}$, са друге.

За тачку $X$ кажемо да раздваја скупове $\mathcal{M}$ и $\mathcal{N}$.

Слично се доказује да важи и Дедекиндова теорема за полуправу и Дедекиндова теорема за дуж. Ако се претпостави да уз аксиоме прве три групе важи и Дедекиндова теорема за дужи, тада важе и Архимедова и Канторова аксиома.

Теорема 6. Ако уз аксиоме прве три групе важи и Дедекиндова теорема за дужи, тада важе и Архимедова и Канторова аксиома.

Доказ. Ако претпоставимо да постоје дужи $A B$ и $C D$ и низ тачака $A_{1}, A_{2}, \ldots, A_{n}, \ldots$ на полуправој $A B$ таквих да је $\mathcal{B}\left(A_{1}, A_{2}, \ldots, A_{n}, \ldots\right)$ а све дужи $A A_{1}, A_{1} A_{2}, \ldots, A_{n-1} A_{n}, \ldots$ су подударне дужи $C D$ и садржане су у дужи $[A B]$ тада скуп тачака дужи $[A B]$ можемо поделити у два подскупа $\mathcal{M}$ и $\mathcal{N}$, таква да су у скупу $\mathcal{M}$ све тачке које припадају дужима $\left[A A_{1}\right),\left[A_{1} A_{2}\right), \ldots,\left[A_{n-1} A_{n}\right), \ldots$, а у скупу $\mathcal{N}$ све остале тачке дужи $[A B]$. Како скупови $\mathcal{M}$ и $\mathcal{N}$ задовољавају услове Дедекиндове теореме за дужи, постојаће тачка $X$ која раздваја скупове $\mathcal{M}$ и $\mathcal{N}$. Ако је $Y$ тачка праве $A B$ са оне стране тачке $X$ са које је $A$, таква да је $X Y \cong C D$, 
тада је тачка $Y$ у скупу $\mathcal{M}$, па припада некој дужи $\left[A A_{1}\right),\left[A_{1} A_{2}\right), \ldots,\left[A_{n-1} A_{n}\right), \ldots$, на пример дужи $A_{i-1} A_{i}$, што је немогуће јер би тада тачке $A_{i}$ и $A_{i-1}$ припадају отвореној дужи $X Y$, а $X Y \cong C D \cong A_{i} A_{i-1} \mathrm{XY} \cong \mathrm{CD}$. Тиме је доказана Архимедова аксиома.

Да бисмо доказали Канторову аксиому, претпоставимо да је $\left[A A_{1}\right],\left[A_{1} A_{2}\right], \ldots,\left[A_{n-1} A_{n}\right], \ldots$ низ затворених дужи неке праве, таквих да свака од тих дужи садржи следећу. Можемо претпоставити да је $\mathcal{B}$ $\left(A_{1}, A_{2}, \ldots, A_{n}, \ldots, B_{n}, \ldots, B_{2}, B_{1}\right)$, скуп тачака дужи $\left[A_{1} B_{1}\right]$. Како скупови $\mathcal{M}$ и $\mathcal{N}$ задовољавају услове Дедекиндове теореме за дужи, постојаће тачка $X$ која раздваја скупове $\mathcal{M}$ и $\mathcal{N}$. Како је за свако $i$, између тачака $A_{i}$ и $B_{i}$, тачка $X$ припада свакој дужи низа $\left[A_{1} B_{1}\right],\left[A_{2} B_{2}\right], \ldots,\left[A_{n} B_{n}\right] \ldots$ Тиме је доказано да су Архимедова и Канторова аксиома последица Дедекиндове теореме.

\section{4. Последице аксиома непрекидности}

Многе теореме које су наизглед очигледне не могу се доказати без примене аксиома непрекидности. Ево неколико примера таквих теорема.

Теорема 7. Ако је дат круг $k(O, r)$ и тачка $P$ унутар круга $k$ тада произвољна права $l$ у равни круга $k$, која садржи тачку $P$ има са кругом $k$ две заједничке тачке.

Доказ. Могу наступити два случаја:

- права $l$ садржи средиште $O$ круга $k$,

- права $l$ не садржи средиште $O$ круга $k$.

Први случај. Нека тачка $O$ припада правој $l$. Тада постоје тачке $X$ и $Y$ на правој $l$ са разних страна тачке $O$, такве да је $O X \cong r$ и $O Y \cong r$, па права $l$ има са кругом $k(O, r)$ две заједничке тачке $X$ и $Y$.

Други случај. Нека сада тачка $O$ не припада правој $l$. Означимо са $A_{0}$ подножје нормале из тачке $O$ на правој $l$. Тада ће бити $O A_{0} \leq O P$. Како је тачка $P$ унутар круга $k$, биће $O P<r$, те је и $O A_{0}<r$. Одредимо на правој $l$ са било које стране тачке $A_{0}$ тачку $B_{0}$ такву да је $A_{0} B_{0} \cong r$.

У правоуглом троуглу $O A_{0} B_{0}$ хипотенуза $O B_{0}$ је већа од катете $A_{0} B_{0}$ па

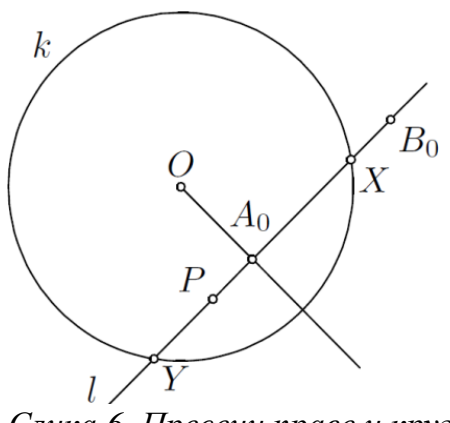

Слика 6. Пресещи праве и круга 
je $O B_{0}>r$, тј. тачка $B_{0}$ је ван круга $k$. Нека је $C_{0}$ средиште дужи $A_{0} B_{0}$. У том случају за тачку $C_{0}$ могу наступити три могућности: $O C_{0} \cong r, O C_{0}<r$ и $O C_{0}>r$.

Ако је $O C_{0} \cong r$, тврђење следи непосредно. Ако је тачка $C_{0}$ унутар круга $k$, означимо са $A_{1}$ тачку $C_{0}$, а са $B_{1}$ тачку $B_{0}$. Ако је тачка $C_{0}$ изван круга $k$, означимо са $A_{1}$ тачку $A_{0}$, а са $B_{1}$ тачку $C_{0}$. У оба случаја је $O A_{1}<r$ и $O B_{1}>r$, дуж $A_{1} B_{1}$ је једнака половини дужи $A_{0} B_{0}$ и садржана је у њој. Означимо са $C_{1}$ средиште дужи $A_{1} B_{1}$. За тачку $C_{1}$ имамо следеће могућности: $O C_{1} \cong r, O C_{1}<r$ и $O C_{1}>r$. Ако је $O C_{1}>r$ обележимо са $A_{2}$ тачку $A_{1}$, а са $B_{2}$ тачку $C_{1}$, а ако је $O C_{1}<r$, онда означимо са $A_{2}$ тачку $C_{1}$, а са $B_{2}$ тачку $B_{1}$. У оба случаја је $O A_{2}<r, O B_{2}>r$, па је дуж $A_{2} B_{2}$ једнака половини дужи $A_{1} B_{1}$ и садржана је у њој.

Настављајући тај поступак после $n$ корака добијамо да је:

$$
O A_{n}<r, \quad O B_{n}>r, \quad A_{n} B_{n}=\frac{1}{2^{n}} A_{0} B_{0}, \quad\left[A_{n} B_{n}\right] \subset\left[A_{n-1} B_{n-1}\right] .
$$

Према томе, добили смо низ затворених дужи $\left[A_{n} B_{n}\right]$ за који је испуњена Канторова аксиома и не постоји дуж садржана у свим дужима тог низа.

Заиста, јер ако би постојала таква дуж $d$ која би припадала свим дужима тог низа дужи, тада број $n$ можемо изабрати тако да дуж $\left[A_{n} B_{n}\right]$ буде мања од било које унапред задате дужи, па и од дужи $d$, па би већа дуж $d$ била садржана у мањој дужи $A_{n} B_{n}$, што је немогуће.

Дакле, низ $\left(A_{n} B_{n}\right)$ је Канторов низ, па на основу теореме 3 постоји јединствена тачка $X$ која припада свим дужима тог низа дужи. Докажимо да тачка $X$ припада кругу $k$, тј. да је једна од пресечених тачака праве $l$ и круга $k$. Довољно је да докажемо да је $O X \cong r$. За дужи $O X$ и $r$ важи тачно једна од следећих три могућности: $O X<r$, $O X>r, O X \cong r$.

Нека је $O X<r$. Тада постоји нека дуж $\varepsilon$ таква да је $O X=r-\varepsilon$. Из троугла $O X B_{n}$ имамо $O B_{n}<O X+X B_{n}$. Тачка $X$ припада дужи $\left[A_{n} B_{n}\right]$, па је $X B_{n}<A_{n} B_{n}$. Можемо изабрати довољно велики број $n$, такав да дуж $\left[A_{n} B_{n}\right]$ буде мања од било које унапред задате дужи $\varepsilon$. Тада је $X B_{n}<\varepsilon$, па је $O B_{n}<r-\varepsilon+\varepsilon=r$. Дакле, добили смо да тачка $B_{n}$ припада унутрашњости круга што представља контрадикцију. Према томе није $O X<r$. Аналогно се доказује да није $O X>r$. 
Значи, мора бити $O X \cong r$, тј. тачка $X$ припада кругу $k$.

За тачку $Y$ праве $l$ симетричну тачки $X$ у односу на тачку $A_{0}$ непосредно се добија да припада кругу $k$. Дакле, права $l$ и круг $k$ имају две заједничке тачке $X$ и $Y$ Није тешко закључити да, осим двеју тачака, круг $k$ и прва $l$ немају других заједничких тачака.

Теорема 8. Ако два круга $k$ и $k^{\prime}$ припадају једној равни и ако један од та два круга, нпр. $k^{\prime}$ садржи неку тачку $A$ која се налази унутар круга $k$ и неку тачку $B$ ван круга $k$, тада кругови $k$ и $k^{\prime}$ имају две заједничке тачке.

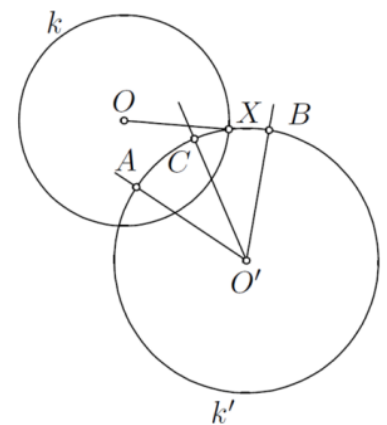

Слика 7. Пресеичи два круга

Доказ. Нека су $O$ и $O^{\prime}$ средишта, а $r$ и $r^{\prime}$ полупречници редом кругова $k$ и $k^{\prime}$. Означимо са $s$ медијатрису једног од углова $\angle A O^{\prime} B$. Полуправа $s$ има са кругом $k^{\prime}$ једну заједничку тачку, означимо је са $C$. При томе је или $O C \cong r, O C<r$ или $O C>r$. Ако је $O C \cong r$, тада је тачка $O$ једна заједничка тачка кругова $k$ и $k^{\prime}$. Ако је $O C<r$, обележимо са $A_{1}$ тачку $C$ а са $B_{1}$ тачку $B$. Ако је пак $O C>r$, обележимо ca $A_{1}$ тачку $A$ а са $B_{1}$ тачку $C$. У оба случаја је $O A_{1}<r, O B_{1}>r$ и $\angle A_{1} O^{\prime} B_{1}=\frac{1}{2} \angle A O^{\prime} B$.

Конструишимо медијатрису угла $A_{1} O^{\prime} B_{1}$ и означимо са $C_{1}$ заједничку тачку медијатрисе $s_{1}$ и круга $k^{\prime}$. За тачку $C_{1}$ постоје три могућности: $O C_{1} \cong r, O C_{1}<r$ или $O C_{1}>r$. Ако је $O C_{1} \cong r$, тада је тачка $C_{1}$ заједничка тачка кругова $k$ и $k^{\prime}$. Ако је $O C_{1}<r$, означимо са $A_{2}$ тачку $C_{1}$ a са $B_{2}$ тачку $B_{1}$, а ако је пак $O C_{1}>r$, онда означимо са $A_{2}$ тачку $A_{1}$ а са $B_{2}$ тачку $C_{1}$. Тада је у оба случаја $O A_{2}<r, O B_{2}>r$ и $\angle A_{2} O^{\prime} B_{2}=\frac{1}{2^{2}} \angle A O^{\prime} B$. 
Настављајући тај поступак добијамо тачке $A_{n}$ и $B_{n}$ такве да је $O A_{n}<r, O B_{n}>r$ и $\angle A_{n} O^{\prime} B_{n}=\frac{1}{2^{n}} \angle A O^{\prime} B$. На тај начин је добијен неограничени низ затворених углова који задовољава Канторову аксиому за углове и не постоји угао садржан у свим угловима тога низа.

Тада, према Канторовој теореми за углове следи да постоји јединствена полуправа $s^{\prime}$, садржана у свим угловима тог низа. Означимо са $X$ тачку те полуправе, такву да је $O^{\prime} X \cong r^{\prime}$, то јест тачку у којој полуправа $s^{\prime}$ сече круг $k^{\prime}$. Докажимо да тачка $X$ припада и кругу $k$. У том случају за тачку $X$ могу наступити три могућности: $O X<r$, $O X>r$ или $O X \cong r$.

Нека је $O X<r$. У том случају постоји нека дуж $\varepsilon$ таква да је $O X=r-\varepsilon$. У троуглу $O X B_{n}$ је $O B_{n}<O X+X B_{n}$. Број $n$ можемо изабрати тако да тетива $A_{n} B_{n}$ буде мања од било које унапред задате дужи $\varepsilon$. Како је тачка $X$ унутрашња тачка дужи $\left[A_{n} B_{n}\right]$ то је $X B_{n}<A_{n} B_{n}$ па je $X B_{n}<\varepsilon$. Према томе, имамо да је $O B_{n}<r-\varepsilon+\varepsilon=r$, па је $B_{n}$ унутрашња тачка круга $k$, што је у контрадикцији са конструкцијом низа тачака $B_{0}, B_{1}, B_{2} \ldots$ Дакле није $O X<r$.

На потпуно исти начин и претпоставка $O X>r$ доводи до контрадикције.

Према томе, мора бити $O X \cong r$, тј. тачка $X$ припада кругу $k$. Разматрањем другог угла $A O^{\prime} B$ аналогним поступком добијамо другу пресечну тачку $Y$ кругова $k$ и $k^{\prime}$.

\section{5. Закључак}

Помоћу претходних разматрања захтев непрекидности је разложен на два различита дела. Према Архимедовој аксиоми, свака тачка праве, ма колико далеко била, може се достићи коначним бројем преношења задате дужи. Канторова аксиома непосредно тврди да је права густо испуњена тачкама. Међутим, уместо аксиома непрекидности у аксиоматском заснивању геометријске непрекидности можемо узети само Дедекиндову теорему пошто је показано да је Дедекиндова теорема еквивалентна конјункцији Архимедове и Канторове аксиоме. Напоменимо још и то да је Хилбертова аксиома линеарне потпуности еквивалента Канторовој аксиоми.

Без аксиома непрекидности немогуће је показати да раван $\pi$, која садржи произвољну тачку $P$ унутар неке сфере $S(O, r)$ са том сфером има непразан пресек. Такође, није могуће показати да сфера $S(O, r)$, која садржи произвољну тачку $P$ унутар неке сфере $S_{1}\left(O_{1}, r_{1}\right)$ и неку тачку $Q$ изван те сфере, са сфером $S$ има непразан пресек. У оба случаја пресек је круг. 


\section{Литература}

1. Еуклид (1957). Елементи. Београд: Научна књига.

2. Лопандић, Д. (1979). Геометрија. Београд: Научна књига.

3. Лучић, 3. (1997). Еуклидска и хиперболичка геометрија. Београд: Математички факултет, Београд.

4. Лучић, 3. (2009). Огледи из историје античке геометрије. Београд: Службени гласник.

5. Martin, G. (1982). The Foundations of Geometry and the Non-Euclidean Plane. New York: Intext Educational Publishers.

6. Станковић М. (2006). Основи геометрије. Ниш: Природно математички факултет, Ниш.

7. Хилберт, Д. (1957). Основе геометрије. Београд: Научно дело.

8. Червар, Б., Ерцег Г., Лекић И. (2012). Основе геометрије Преузето Октобра 22, 2013. ca WWW: http://www.pmfst.hr/ gorerc/OG-materijali/OG-201213.pdf

Ms Marko Stankovic

\section{THE GEOMETRIC CONTINUITY}

Summary: The aim of this paper is modern establishment of geometric theory of continuity, which is based on two, fourth group axioms - Archimedes' and Cantor's axiom. Various consequences of Archimedes' and Cantor's axioms are proven such as Cantor's and Dedekind's theorem. The paper gives a special view on Hilbert's axiomatic establishment of geometry which uses axiom of linear completeness instead of Cantor's axiom. Finally, the paper illustrates the use of the axioms of continuity and their consequences in proving some theorems.

Key words: Axioms of continuity, Archimedes' axiom, Cantor's axiom, Dedekind's theorem, Axiom of linear completeness.

Примљено: 26. 10. 2013. године.

Одобрено за штампу: 28. 11. 2013. године. 